\title{
Economic Analysis of Coconut in West Godavari District of Andhra Pradesh
}

\author{
K.Venkat Reddy ${ }^{1}$, Dr.Prabhu Kumar ${ }^{2}$, Dr.S.V.Ramana Rao \\ ${ }^{I}$ Research scholar, management science, JNTUH, Hyderabad \\ ${ }^{2}$ Director I/C school of management (SMS) ,JNTUH, hyderabad-500085 \\ ${ }^{3}$ Principle scientist ICAR-IIOR, Hyderabad
}

\begin{abstract}
The present study is an attempt to analyze the feasibility of investment in coconut orchards and to find out the profitability of coconut crop. So, present study was taken up with overall objective of enquiring into economics of coconut production with the objectives to examine the per hectare resource use pattern and costs and return structure, to study problems faced in production of coconut growers. The methodology adopted was, on the basis of area under highest area under coconut cultivation west Godavari districts was selected purposively. The annual per hectare cost of production (Cost C) for coconut worked out to Rs. 58425.35. The analysis of investment in coconut orchard showed that, the investment made in coconut plantation is economically viable with Benefit cost ratio (BCR) greater than unity(1.23), Net present value (NPV) was positive (Rs. 47371.18) and Internal rate of return (IIR) was higher than prevailing rate of interest (12\%).
\end{abstract}

Key Words: coconut Cost, and Return, Financial feasibility, NPV, BCR, , IRR

\section{Introduction}

Among the oilseed palm trees, coconut palm hardly needs any emphasis on its multi-utility significance. The economic importance of this tree crop is evident from the fact that it ingrown in more than 90 countries across the world in an area of 14.231 million hectares producing about 57.514 billion nuts or 10.52 million tones of copra. However, Philippines, Indonesia, India and Sri Lanka account for 78 per cent of the area and production. India ranks third on world coconut map and in recent times became the largest producer of coconut with the production of 16.9 billion nuts from average under plantation of about 1.89 million hectares. Even though India is among the largest producer of coconut with a distinction of having the highest productivity of 7779 nuts per hectare as against 3630 nuts per hectare in Indonesia and 3859 nuts per hectare in Philippines, the per capita annual availability of coconut estimated to have been 10 nuts only which is quite low compared to 222 of Philippines, 145 of Sri Lanka and 55 nuts of Indonesia. The productivity too, India ranks number one among other coconut growing countries in the world. The average productivity of coconut in the country is 6898 nut per ha. Among the four major coconut growing states, Tamil Nadu has the highest productivity (11620 nuts/ha), Andhra Pradesh has productivity of 8296 nuts/ha,

\section{Need for the Study and Objectives}

Besides being a rich source of nutrients, cultivation of Coconut brings higher income to the farmers. It is possible to have value addition through processing, which in offers vast opportunities for employment and income generation. So far very few research studies have been attempted to study the economic aspects of coconut production in Andhra Pradesh in general and west Godavari district in particular. Hence, the present study was undertaken with the following objectives:

Objective

- To estimate per hectare costs and return of coconut orchard

- To study the economic feasibility of coconut

- To study the problems faced in production of coconut

\section{Methodology}

Multistage stratified random sampling technique was employed for the selection of the district, mandals, villages and farmer respondents. West Godavari district in was purposively selected for the study based on maximum area in the state under coconut. In this district coconut is grown over an area of 21,200 hectares. In west Godavari district, all the mandals having orchards were arranged in the descending order of the area under coconut and five mandals viz., nidadavole, nallagerla, achanta, elamanchi and Pedavegi which have largest area under coconut were selected purposively for the present study. Two villages from each selected mandal were chosen purposively using the above said procedure making the total number of selected villages to 10.The list of farmers growing coconut in the selected villages was obtained from their respective village records. From the list of coconut growers, a total of 80 farmers were randomly selected for studying the production aspect of coconut 


\section{Computation of costs and returns}

\section{Analysis Of Cost F Ocultivation Of Coconut}

Coconut is a perennial crop with an economic life span 25 years and starts yielding from 5th year onwards. Hence the cost incurred can be classified into two categories viz.,

Establishment cost and

Maintenance costs

Establishment cost: The costs include land preparation, digging and filling of pits, cost of plant material, manures, fertilizers, plant protection chemicals, expenditure incurred on different operations viz., weeding, irrigation, watch and ward and on miscellaneous items like fencing, electricity charges and repairs and maintenance.

Maintenance cost: Expenses incurred on material inputs viz., manures, fertilizers, plant protection chemicals and on human labour utilized for application of material inputs, weeding, channel maintenance, irrigation and electricity charges and repairs and maintenance were considered as maintenance costs during bearing period.

\section{Cost concepts}

These were used to estimate the cost of cultivation of coconut . Cost of

cultivation was generated from the following cost concepts. The cost concepts viz., Cost A

and Cost $\mathrm{B}$ and Cost $\mathrm{C}$ were used in the present study and these are derived as

follows.

\section{Cost A}

This cost includes value of:

i) Hired human labour

ii) Hired bullock labour

iii) Owned bullock labour

iv) Owned and hired machinery services

v) Seeds (both farm produced and purchased)

vi) FYM (owned and purchased)

vii) Fertilizers

viii) Plant protection chemicals (insecticides and pesticides)

ix) Depreciation on implements and farm buildings.

$x)$ Land revenue, Cess and other taxes

xi) Interest on working capital

xii) Irrigation charges

xiii) Miscellaneous expenses (artisans, etc)

Cost B

Cost A + imputed rental value of owned land + interest on owned fixed capital

Cost $\mathrm{C}$

Cost B + imputed value of family labour. It gives the total cost of cultivation (or) total cost.

3.4.2 Farm income measures (returns)

Gross Income (GI): This represents the total amount of money obtained by the producers from the sale of coconut.

Farm Business Income (FBI): This is the returns to the farm operator for his management, family labour contribution and investment on land fixed capital.

FBI $=$ Gross Income - Cost A

Net Income (NI): This refers to the surplus of gross income over the total costs, i.e.commercial cost of cultivation (Cost ' $\mathrm{C}$ ').

NI $=$ Gross income - Cost $C$

Farm Labour Income (FLI): It is a measure of returns for family labour in the cultivation of coconut

FLI $=$ Gross income - Cost $B$

\section{Farm Investment Income (FII)}

This measure of income indicates the returns to capital invested in the farm and computed from the following equation.

FII $=$ Net Income + Rental value of owned land and interest on owned fixed capital.

\section{Project Evaluation techniques}

\section{Financial feasibility analysis:}

The economic evaluation of investment in coconut orchard was carried out by developing year wise cash outflows and cash inflows for the coconut orchard for the life period of 25 years. The financial feasibility of investment in coconut orchard for both categories is judged with the help of following financial feasibility tests. Net present value (NPV) : 
It is the discounted value of net cash flow of the coconut orchard during its life time. Generally higher NPV would be the preference. In calculating NPV the present value benefit was considered at 12 per cent discount rate. The NPV is computed as :

$$
{\underset{t}{N P V}=\Sigma}_{(1+r)^{t}}
$$

were,

$\mathrm{R}_{\mathrm{t}}=$ Returns in period ' $\mathrm{t}$ ' $\mathrm{C}_{\mathrm{t}}=$ Cost in period ' $\mathrm{t}$ '

$\mathrm{r}=$ Discount rate $\mathrm{t}=$ Project life.

For viability of investment NPV should be positive at prevailing rate of interest.

Pay back period (PBP) :

It indicates the time period required to recover the initial investment made in a project. Shorter the pay back period, better it will be, and then the investment in a project considered feasible. Symbolically :

$$
\begin{aligned}
& \mathbf{t} t \\
& \sum \mathbf{C}_{\mathbf{t}}=\sum \mathbf{R}_{\mathbf{t}} \\
& \mathbf{t}=\mathbf{t}=\mathbf{0}
\end{aligned}
$$

. where,

$\mathrm{R}_{\mathrm{t}}=$ Return in period ' $\mathrm{t}$ '

$\mathrm{C}_{\mathrm{t}}=$ Cost in period ' $\mathrm{t}$ '.

Benefit cost ratio $(B C R)$ :

It is the ratio of the discounted value of all cash inflows to the discounted value of cost outflows during life of project. It is computed as :

$\sum \mathbf{R}_{\mathrm{t}}(\mathbf{1}+\mathbf{r})^{-\mathrm{t}}$

$\mathbf{B C R}={ }^{\mathrm{t}=0}$

$\sum \mathbf{C}_{\mathrm{t}}(\mathbf{1}+\mathbf{r})^{-\mathrm{t}} \mathbf{t}=\mathbf{0}$

If $\mathrm{BCR}$ is greater than one, the investment is considered feasible.

Internal rate of return (IRR):

The internal rate of return is that rate of discount at which NPV is zero. The internal rate of return is arrived at, through interpolation technique by using different discount rates so as to see that net present value is equated to zero. It is calculated by using following formula:

$\operatorname{IRR}=\Sigma \operatorname{Rt}(\mathbf{1}+\mathbf{r})-\mathbf{n}-\Sigma \mathbf{C t}(\mathbf{1}+\mathbf{r})-\mathbf{n}=\mathbf{0}$

If IRR is greater than prevailing rate of interest then investment is feasible.

\section{Results and Discussion}

\section{Cost Structure}

Coconut is one of the major crop occupying a prominent place in the economy of cultivators and India is the leading country in the world for coconut production. Therefore, cost of cultivation has paramount importance in determining the net income from it.

Table.1. Establishment cost of coconut orchard during first year (Rs/ha)

\begin{tabular}{|c|c|c|c|}
\hline S.No. & Operation & Cost(Rs.) & $\begin{array}{c}\text { Percentage to } \\
\text { Total }\end{array}$ \\
\hline 1 & Land preparation & 2343.21 & 13.07 \\
\hline 2 & Making lines, digging pits & 2391.09 & 13.33 \\
\hline 3 & Fertilization & 746.23 & 4.16 \\
\hline 4 & Weeding & 1225.35 & 6.83 \\
\hline 5 & Live fencing & 630.23 & 3.51 \\
\hline 6 & Manuring & 2334.73 & 13.02 \\
\hline 7 & Irrigation application & 2345.85 & 13.08 \\
\hline 8 & Planting material & 4637.24 & 25.86 \\
\hline 9 & Planting & 1272.54 & 7.09 \\
\hline $\mathbf{1 0}$ & & $\mathbf{1 7 9 2 6 . 4 7}$ & $\mathbf{1 0 0}$ \\
\hline
\end{tabular}


Table .2. The cost of cultivation of coconut per hectare per year

\begin{tabular}{|c|c|c|c|}
\hline S.No. & Particulars & Costs & Percentage to Total \\
\hline $\mathrm{A}$ & direct costs & & \\
\hline 1 & Bullock labour(owned) & 789.09 & 1.35 \\
\hline \multirow[t]{3}{*}{2} & Tractor labour & & \\
\hline & a. Owned & 820.14 & 1.40 \\
\hline & b.hired & 1100.24 & 1.88 \\
\hline 3 & Land preparation & 2477.03 & 4.23 \\
\hline 4 & Hired labour & 3754.21 & 6.42 \\
\hline 5 & Micro nutrients & 820.45 & 1.40 \\
\hline 6 & Irrigation watch and ward & 2776.47 & 4.75 \\
\hline 7 & harvesting & 2760.14 & 4.72 \\
\hline 8 & pruning & 1232.47 & 2.10 \\
\hline 9 & Manuring & $4,121.92$ & 7.05 \\
\hline 10 & Fertilization & $1,742.86$ & 2.98 \\
\hline 11 & Electricity charges & 812.20 & 1.22 \\
\hline 12 & Repairs and maintenance & 507.16 & 0.86 \\
\hline 13 & Plant protection & 2357.88 & 4.06 \\
\hline \multirow[t]{2}{*}{14} & Interest on working capital & $3,173.55$ & 4.03 \\
\hline & Sub Total (A) & 29247.56 & 50.05 \\
\hline B & indirect costs & & \\
\hline 2 & Land revenue & 24.56 & 0.04 \\
\hline 3 & Rental value of owned land & 22845.52 & 39.10 \\
\hline 4 & Depreciation & 296.70 & 0.50 \\
\hline 5 & Interest on fixed capital & $1,668.45$ & 2.85 \\
\hline \multirow{4}{*}{6} & & $4,342.03$ & 7.43 \\
\hline & Annual share of establishment cost & & \\
\hline & Sub Total (B) & 29177.23 & 49.93 \\
\hline & Grand Total $(\mathrm{A}+\mathrm{B})$ & 58425.35 & 100 \\
\hline & & & \\
\hline
\end{tabular}

Table .3. Cost concepts of coconut (Rs/ha)

\begin{tabular}{|l|l|l|}
\hline S.No. & Particulars & Value (Rs) \\
\hline 1. & Cost A & $29,247.56$ \\
\hline 2. & Cost B & 53760.45 \\
\hline 3. & Cost C & 58425.35 \\
\hline
\end{tabular}

Table.4.Income measures of coconut (Rs/ha)

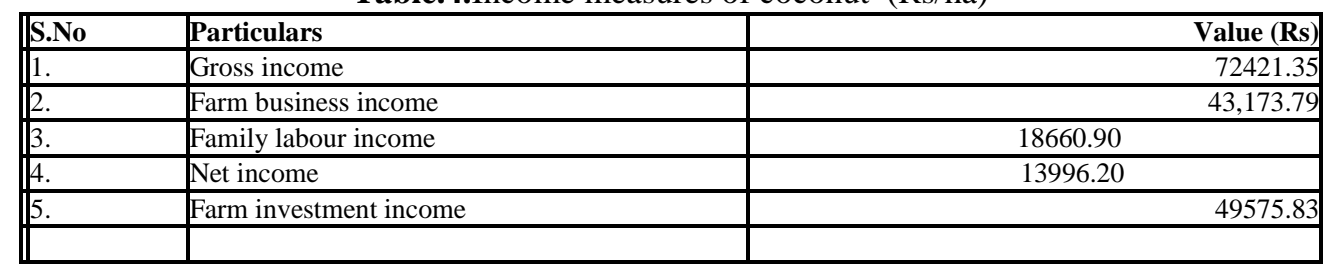

\section{Net present worth}

\section{Discounted Cash Flow Techniques}

The net present worth per hectare for coconut was worked out At 12 per cent discount rate. Net present worth of was Rs. 47371.18 found that the investment in coconut orchard was conomically feasible.

\section{Benefit cost ratio}

The benefit cost ratio hectare for coconut was worked out. At 12 per cent discount rate. The benefit cost ratio of coconut orchard at 12 percent discount rate was 1.23 Thus the discounted benefit cost ratio which indicates the rate of returns for a rupee of capital investment reiterated that the investment on coconut production was quite profitable. 


\section{Internal rate of return}

The Internal rate of return in hectare for coconut orchard was worked out Internal rate of return in coconut orchard was 24.25 percent which is favorable nature of returns and it is also higher than the present market rate of interest

\section{Production Constraints}

In this study observed that of planting the high cost material (78.43 per cent), non availability of high yielding varieties of coconut (73.33 per cent), Lack knowledge about identifying pests (58.46 per cent), non availability of labor in time (56.45 per cent), Long distant of market (70.83 per cent), non availability of fertilizer in time (60.83 per cent), High cost of labor (58.33 per cent), Fluctuation in market prices (55.83 per cent), High cost of fertilizer (49.17 per cent), Un-even payment for sale (38.33 per cent) and Lack of knowledge about identifying the disease ( 25.83 per cent) were the major production and marketing constraints encountered by the coconut sampled farmers.

\section{Conclusion}

The analysis of investment in coconut orchard showed that the investment made in coconut plantation is economically viable with the NPV found to be positive, the B:C ratio of coconut orchard is also greater than unity and IRR was found to be 24.25 per cent which is higher than prevailing interest rate on borrowing

The fallowing conclusions have been drawn from the results of the present study

1. The average establishment cost of coconut 17926.47 during first year in per hectare.

2. Rental value of owned land was the major item of cost among the fixed costs.

3. Cost A and cost B and cost C were, Rs. 29247.56, Rs. 53760.45 and Rs.58425.35 respectively in coconut orchards.

4. The total gross returns, net return were, Rs. 72421.35 and Rs. 13996.20 Respectively in coconut orchards

\section{Reference}

[1]. Ramanathan,T., S.Thangavelu, C.S. Sridharan and S. Alamelu, Performance of coconut cultivars and hybrids under semi dry condition, Indian Coconut Journal, 1992.

[2]. Rathinam, P.K., and P.K.Thamban, "Blue Print for Reviving Coconut based economy of Defrala State", Kisan World, V.29(1-6) June 2002

[3]. Ravindranatha, S.A., "Inaugural Address",-National Conference on Coconut,Indian Coconut Journal” CDB, Kochi. Vol.LIII No.9 Jan 2011.

[4]. Remony Gopala krishnan, "APCC-An Intergovernmental organization for the cause of coconut Industry", "Indian Coconut Journal" CDB, Cochi.Vol.No.LIV No.6, October 2011.

[5]. "Report on Copra", National Multi-Commodity Exchange of India Limited, Ahmadabad, 2008.

[6]. Resmi D.S., "Coconut industry: Decades of poverty, decades of waiting”,Phillippine Daily Inquirer, Mar 2013.SowmitraTrivedi, "Coconut growers reducing plantations", Business Standard, Apr.2007.

[7]. Sreedevi Chitharanjan, "Coconut Cultivation no longer a male domain", The Times of India, Kozhikode, Nov 2011 